\title{
Turkish Migrant Associations in Germany: Between Integration Pressure and Transnational Linkages
}

Les associations turques de migrants en Allemagne: entre pression à

l'intégration et liens transnationaux

Las asociaciones de migrantes turcos en Alemania: entre la presión de la

integración y las vinculaciones transnacionales

\section{Anna Amelina and Thomas Faist}

\section{(Q) OpenEdition}

\section{Journals}

Electronic version

URL: https://journals.openedition.org/remi/4542

DOI: $10.4000 /$ remi.4542

ISSN: $1777-5418$

\section{Publisher}

Université de Poitiers

\section{Printed version}

Date of publication: 1 November 2008

Number of pages: $91-120$

ISBN: 978-2-911627-49-0

ISSN: 0765-0752

\section{Electronic reference}

Anna Amelina and Thomas Faist, "Turkish Migrant Associations in Germany: Between Integration

Pressure and Transnational Linkages", Revue européenne des migrations internationales [Online], vol. 24 - $\mathrm{n}^{\circ} 2$ | 2008, Online since 01 November 2011, connection on 14 April 2022. URL: http:// journals.openedition.org/remi/4542 ; DOI: https://doi.org/10.4000/remi.4542 


\title{
Turkish Migrant Associations in Germany: Between Integration Pressure and Transnational Linkages
}

\author{
Anna AMELINA* and Thomas FAIST**
}

There is a tension between integration expectations in immigration countries such as Germany on the one hand and transnational bonds of immigrants on the other hand. In general, transnational ties of immigrants are seen as detrimental to a successful integration of migrants into German society. Thus our central research question is: How do political, economical and religious organizations of Turkish origin immigrants deal with the nationally defined integration requests? Which political practices do migrant organizations develop in this area of conflict between transnational networks and integration pressure? Political practices are action routines which are oriented towards obtaining collectively binding political results. We argue that the public positioning of migrant associations vis-à-vis demands for integration is part of a two-way process of accommodation involving both migrant organizations and groups of 'majority society'.

Usually politicians of the country of immigration regard transnational political practices of migrants as an integration hindrance, which has of late increasingly been discussed by German media? (Geißler/Pöttker, 2006). In this connection, a special interest lies on the changes of the media discussion of "migration" and "migrants", which were caused by the creation of the terrorism discourse. The picture produced by television news of Muslim migrants in Germany has mainly been marked by negativity since $11^{\text {th }}$ September 2001. The nationalities most frequently mentioned in the context of news are Moroccan or Turkish (Ruhrmann/Sommer/Uhlemann, 2006: 45). A characteristic feature of modern television reporting, in contrast to the past ones, is a

* Researcher, Faculty of Sociology, University of Bielefeld, P.O. Box 1001333501 Bielefeld, anna.amelina@uni-bielefeld.de

** Professor of Transstate Relations and Sociology of Development, Faculty of Sociology, University of Bielefeld, P.O. Box 1001333501 Bielefeld, thomas.faist@uni-bielefeld.de 
high journalistic level of recognition which can be explained by visualisation. A current analysis of news reports on German television (Ruhrmann/Sommer/Uhlemann, 2006) shows that such aspects as damage, conflict and aggression are not necessary used for thematical connection of terrorism with migration in the reports. Thus, the constant warnings about suspected extremists living in Germany as well as Islamists immigrating to Germany make up for a considerable part of news reporting.

Additionally, the media integration debate in the press is marked by negativity (Zengingül, 2007 ${ }^{1}$ ). The media especially expounds the problems of integration intention of immigrants: "Whoever wants to live constantly in Germany has obligations". Apart from the mastery of the German language, one has to acknowledge the basic values of the German society. Especially those migrants who did not learn about democratic or human rights ideals show the largest amount of integration deficits. Terms such as "Turks" and "Muslims" are usually used as synonyms.

We link up to the thesis that transnational ties are harmful for integration in the immigration country in a specific way. First of all, we assume that migrant organizations in Germany take note of integration requests and are, therefore, likely to deal with integration pressure (Østergaard-Nielsen, 2003; Rauer, 2008). Second, we consider that migrant organizations interpret the public integration offers, which certainly vary for different categories of migrants, in different ways. Thus, the central research question can be formulated as the following: Which political practices do migrant organizations develop in this area of tension between actually existing transnational networks on the one hand and integration pressure into the immigration country on the other hand?

Our research is focused on three types of migrant associations - religious, political and business organizations - whose members are of Turkish background. The great number of these associations is characterized by transnational linkages. They are transnational in the sense that they maintain contacts to political representatives in both countries, Germany and Turkey. The aims and strategies of them are also marked by an orientation towards political questions in both countries. Although the members of associations not necessarily circulate between two countries, the decisions about their political participation depend on their knowledge about two different institutional political backgrounds. We decided to analyze religious, political and business associations, because the dominant public integration discourse in German media primarily addresses these associations (Rauer, 2008). Apart from this, we assume that these organizations produce the largest amount of political practices concerning integration requests. In general, political activities, such as demonstrations, public discussion performances, mass gatherings, representation activities for public institutions, can be named as the most spread political work of the associations. Methodologically our research was directed by grounded theory (Strauss, 2007).

1 Three newspapers - the Frankfurter Allgemeine Zeitung (FAZ), Süddeutsche Zeitung (SZ) and Tageszeitung (TAZ) were analysed in reference to their content, in the time period from 3.11.2004 till 24.1.2004. 
Between 2005 and 2006 ten expert interviews with the representatives of migrant associations were conducted. Additional sources, like internet-homepages of the associations were also evaluated (cf. Appendix).

After specifying the theoretical frame of research (cf. 2) we examine the political activities of religious associations, such as DITIB, AABF, IGMG, (cf. 3). Thus, the activities of political associations (TGD, DIDF) and economic associations (ATIAD, Müsiad Berlin, TDU, TD-IHK) of migrants are, therefore, analyzed as well (cf. 4, 5). The short conclusion completes the paper.

\section{THEORETICAL FRAME}

While media reporting on transnational political practices of migrants is characterized by the one-sidedness, the sociological debate over the significance of transnational bonds for integration processes varies. On the one hand, we have approaches which define migrants relations to the homeland as a hindrance to integration, such as the assimilation theory by Esser (2001) and the cultural deficit approach by Heitmeyer (Heitmeyer at.al., 1997). Both concepts suppose that cultural adjustment of migrants has to be seen as a condition of structural integration. On the other hand, there are transnational approaches (Faist, 2000; Koopmans and Statham, 2001; Pries, 2008), which have a more multifaceted view on the connection between integration and transnational linkages.

Therefore, our research is based on transnational approaches that pay attention to the ways in which migrant collectives structure their social and symbolic networks in multiple nation state contexts. Two hypotheses concerning the relation between integration and transnational linkages are formulated from this theoretical perspective. The first one is enunciated by Koopmans and Statham (2001) who explore transnational activities as a result of institutional state pressure put on migrant collectives. In their comparative study of migrants` transnational claim-makings in Germany, the Netherlands and Great Britain Koopmans and Statham argue that national integration regimes have a strong impact on political activities developed by migrants. For the German case they point out that both citizenship law and integration regime, which define migrants as a 'foreign body' of nation state, are the central causes for a comparatively high level of migrants' transnational activities. The formation of socalled 'parallel societies' - e.g. migrant communities which remain to be 'homelandorientated' - is, from this point of view, a home-made matter. In reverse, one can assume that the transnational claim-makings are a hint for failed integration caused - in this case - by nation state opportunities. Concomitantly, this line of argumentation formulates an "action-reaction" relation between state's institutional opportunities and activities of migrant collectives and organizations.

The second hypothesis regarding the connection between integration and transnational linkages is based on the assumption that multiply located political activities are compatible with nation state required integration developments. However, this position avoids the "action-reaction" or the "stimulus-response" assumption. 
Instead, the second hypothesis prefers an alternative understanding of the term "integration". It has to be understood as "positive two-way processes of mutual accommodation between migrants and their host society" (Tambiah, 2000: 168). The accommodation can be situated on different levels of societal life: Firstly, one can observe these processes between institutions of nation states and individuals with migrational background, and, secondly, one can notice a mutual accommodation between state institutions and migrant associations - in other words, on the organizational level.

(Ad 1) The transnational approach suggests that migrants are able, both to maintain transnational linkages and, at the same time, to acquire necessary (economic, political, educational etc.) knowledge in order to achieve an inclusion in organizations and institutions of the 'majority society'. But the transnational concept indicates that not only an adjustment on the part of migrants - which should not be confused with assimilation or acculturation - is necessary to be able to speak of successful integration, but also an adjustment or rather opening up of state or commercial organizations for the new category of clients (Faist, 1995).

(Ad 2) But besides these changes on the individual level, we have to acknowledge that the formation of migrant associations can also be supportive for twoway accommodation processes. On the one hand, they represent and address the collective recognition concerns of migrants to the political authorities. On the other hand, the public authorities of nation states can voice their integration requests to representatives of migrant collectives. Subsequently, the formation of terms, strategies, ideas and rules concerning 'integration' does not occur in the top-down-way - e.g. invented by state and transferred to migrants - but in mutual negotiation processes which include both parts, institutions of nation state and increasingly organized forms of migrant collectives (Tränhardt and Hunger, 2003; Jungk, 2000).

Until now migrant associations, which generally can be divided into those with (ethnically, nationally and religiously) homogeneous and those with heterogeneous members, were either regarded as bridges between migrants and locals (Breton, 1964) or as an expression of collective exclusion (Heitmeyer et. al., 1997). We think that migrant organizations are agents, which, apart from the cultivation of transnational bonds, also raise secondary socialization performances which can be labelled as supportive for a migrant's inclusion. The majority of migrant organizations frequently offer, for example, introductory seminars which pass on the institutional regulations of the immigration country in areas such as economy, politics, health and education. At the same time, state institutions increasingly cooperate with migrant associations in order to legitimize their immigrant and minority politics.

This understanding of integration as a two-way process can be defined with terms of discourse theory (Keller, 2005). From this perspective 'integration' gains a public dimension and can be understood as a public negotiation of social boundaries. These processes of boundary definition refer to a social construction of ethnic or religious minorities. Thus, the minority is not an "objectively" existing group but a result of communicative arguments of at least two groups - a result of social 
comparison (Kneer, 1997). Only the public definition of a social group as an ethnic or religious minority makes the drawing of the social boundaries possible. However, the publicly marked minority group does not have the same access to mass media resources and public situations, in which such definitions are created, as the majority. Under such circumstances the group defined as minority is forced to voice itself as such in order to deal with this labelling. It is important to note that on both sides, the majority and minority groups, only certain social bodies can take part in the 'definition struggles'. While on the majority side national authorities have access to powerful possibilities of definition, migrant associations are the minority side spokespersons in the public negotiation of social boundaries. In order to be recognized in the public discourse, the associations have to present the minority as ethnically and religiously homogeneous ${ }^{2}$. Only such self-ethnicizing, as well as the self-definition as a minority, enables the associations to formulate their claims of recognition (Rauer, 2008: 88).

Even though the associations - in contrast to state authorities - have only restricted access to public definition processes, their political activities cannot solely be regarded as a reaction to the national integration regime. It can rather be assumed that the dominant integration conditions and integration requests are influenced by the associations. From this perspective associations are not passive receiving agents of state conditioned institutional opportunities, but co-constructors of the integration discourse.

To sum up, the article focuses on research results concerning the organizational statements of migrant associations given in the context of the current German integration debate. Concomitantly, the article points out in which way migrant associations connect public statements with the public articulation of their transnational linkages. Finally, we want to describe what kind of public is addressed by migrant associations in both countries - Germany and Turkey.

\section{POLITICAL TOPICS, POSITIONS AND STRATEGIES OF TURKISH RELIGIOUS ASSOCIATIONS}

\section{Turkish-Islamic Union of the Presidency of Religious Affairs (Diyanet İsleri Türk İslam Birligi / DITIB)}

DITIB is the largest Muslim umbrella organization in Germany. The head office, to which 870 Mosque associations are incorporated into, is in Cologne. The umbrella organization was founded by the Committee for Religious Matter (Diyanet İsleri Baskanligi) in 1984. They wanted to ensure that the practicing of religious duties in the European states would not be left to radical organizations. According to a

2 Here group identity is not understood as the sum of constant primordialist characteristics of a social group, but as a socially constructed definition which the group members accept as selfdefinition (Reckwitz, $2001: 22$ ). 
Turkish law from 1963, the committee of the DITIB acknowledges the system of religious belief "Diyanet". From a theological perspective "Diyanet" covers three dimensions of Islamic religiosity: Ibadet (rite), Itikat (religious belief) and Ahlak (morals, morality).

The services of DITIB are mainly directed to Turkish Muslims, even though the association is actually open for all kinds of Muslim. The imams working for the DITIB are civil servants of the Turkish state, who are sent from Turkey for a limited time period. The activities of DITIB are of interest for the research on transnational practices because this example shows that they not only create opportunity structures for transnational activities but can also act as transnational players. However, the assumption that DITIB acts as a state authorities is not quite correct. From a legal perspective DITIB is an independent association founded in Germany. The excerpt from an interview with the general secretary of DITIB, Mehmet Yıldırım, published in the Frankfurter Allgemeine Zeitung newspaper (2005), illustrates the ambiguous relationship of the association with the Turkish state:

"First of all - we don't represent the Diyanet in Ankara but we closely work together concerning one matter. We ask the Diyanet for imams because up to this point they cannot be trained in Germany. They preach at our mosques and stay in Germany for three to four years. We are not a foreign country organization of the Diyanet but an umbrella organization founded in accordance with the German law of association. I am not a member of the Diyanet, and, just as, except for one exception, neither are our board members." 3

Since its foundation, the political activities of DITIB were rather marginal. This has to do with a specific kind of religiousness which does not need any public representation when articulating its belief. This specific religiousness does not connect the belief and its public representation. In opposite, the political representation regime marked by Christianity only defines the publicly represented belief as authentic (Tezcan, 2005). Therefore, DITIB did not initially formulate a political catalogue of demands directed to the German public. However, after gaining experiences with the German political representation regime and the growing public pressure after $9 / 11$, the DITIB started to voice itself politically. To put it into other words, the institutional pressure for public representation of authentic belief, which has grown after 9/11, has changed the way the DITIB deals with the German public. Thus, DITIB's political activities, whose main emphasis is clearly on Germany, can be described as public discussion performances. The addressees of the public statements of the DITIB are in particular German government authorities as well as media public. The majority of activities consists of reactions to public debates related to "Islamist" acts of violence. After the world-wide well-known terrorist attacks as well as the murder of Theo van Gogh in the Netherlands, the expectation has been institutionalised in Germany that Muslim groups have to publicly distance themselves from them. Our main interest is not the question whether this expectation of a distancing is legitimate, but rather the mechanism institutionalised through this expectation.

3 Cf. Interview with the chairman of DITIB Mehmet Yıldırım, in: Frankfurter Allgemeine Zeitung, Date: 09.02.2005. 
On the one hand, a regular request of distancing institutionalises the suspicion against Islam. On the other hand, every single Muslim immigrant has to position himself in relation to his/her belief. This not only leads to a mistrustful examination of the link between Muslim immigrants and "their" associations with a fine-toothed comb, furthermore, it leads to a Muslim common ground: the Umma always sworn by Muslims, the community of Muslims, they are now reproached with. Owing to the public request, the pressure for a public representation of authentic belief can no longer be ignored by the DITIB. Thus, the DITIB does not only have to issue press statements but also organize demonstrations (e.g. the DITIB's demonstration in Cologne in 2004) in order to distance itself from act of terrorism in the name of Islam (Tezcan, 2007).

Apart from intensified political articulations, a close cooperation between DITIB and other Islamic organizations in Germany can be observed after 2001. Subsequently, DITIB takes part in the so-called Islamic conference, which has been organized by the federal Home Office since 2006; additional meetings were held in 2007 and are planned for 2008. These events aim to give both, the German state authorities and the representatives of different Muslim associations, the possibility to discuss questions related to religion, Islamism and integration problems of migrants ${ }^{4}$. One of the central issues of this initiative is the clarification of problems referring to the split between state and religion in Germany. Aside of this, the first Islamic conference (2006) meant to unite various Muslim associations to one contact organization. From the state's point of view, it has to represent the interests of all Muslims living in Germany. This organization was named the "Coordination Committee of Muslims". It connects DITIB with other Muslim associations, such as the "Islam Council" and the "Central Committee of Muslims".

DITIB took also part in the Integration Summit which was initiated by the Federal Home Office $2006^{6}$. The aim of this meeting, which included both, the representatives of the German authorities and of migrant associations, was the development of a so-called "National Integration Plan". Moreover, working groups dealing with relevant integration issues, such as a) "integration courses", b) "German language", c) "education, apprenticeship, apprenticeship market", d) "position/s ituation of women and girls", e) "local integration activities", f) "integration activities for strengthening the common civil society" were formed. Their future proposals should be used for the elaboration of the current integration politics ${ }^{7}$.

4 Cf. www.bmi.bund.de, Date: 01.12.2006.

5 Cf. press releases by the "Coordination Committee of Muslims", www.islam.de, Date 01.12.2007.

6 An additional meeting was organized by the Federal Home Office for 2007. But because of some changes in the German foreigner law, DITIB, together with several other migrant associations, boycotted the summit. (The changes in the law concerned the minimum age of 18 of Turkish women coming to Germany to get married.)

7 Cf. www.bundesregierung.de/Content/DE/Artikel/2006/07/2006-07-14-pressekonferenzintegrationsgipfel.html, Date: November 2006. 


\section{Islamic Community Milli Görüş (IGMG)}

The "Islamic Community Milli Görüş is, next to the DITIB, the most important Turkish-Sunni organization in Germany. However, in contrast to DITIB, this religious organization stands out for its intensive political activities. Its central goal, which is linked to Turkey, is the reorganization of the political order of this country on the basis of the Islamic religion. To put it into other words, "Milli Görüş" strives for a reconstruction of the social order in Turkey. The organizational and spiritual connection between "Milli Görüş" in Germany and its original conservative Islamist party (currently under the title of "Saadet Partisi") in Turkey shows that the success of this organization in Germany cannot solely be explained through endogenous (referring to the immigration country) reasons. Instead, one has to assume that the change of the former Milli Selamet Partisi" to a mass movement ("Refah Partisi Partisi") in the Turkey of the $90^{\text {th }}$ had partly an influence on the success of "Milli Görüş" in Germany.

The "Islamic Community Milli Görüş" (IGMG) defines itself as an Islamic religious community which extensively organises the religious life of Muslims. Apart from fostering the doctrine, preaching of the Islamic religious denomination and widespread fulfilment of the tasks defined by the denomination, the IGMG concerns itself with all matters of Muslims and represents their interests. The IGMG makes an effort to "improve the living conditions of Muslims and the protection of their fundamental rights" .

The history of "Milli Görüş" in Germany started in 1985 when three predecessor organizations combined themselves to an association named „Avrupa Milli Görüş Teskilatlari" ("Organization of the national view in Europe"). In 1995 the umbrella organization was renamed "Islamic Community Milli Görüş" (IGMG) ${ }^{9}$. The IGMG lists, according to its own account, includes altogether 2,060 associations (mosque associations, youth - , women - and university associations etc.) in Germany as well as in Europe, 16679 member of board and 66027 active community members. IGMG emphasizes in its self-representation that it offers religious and social service for 4 million Muslims in Europe. The range of services covers the erection of prayer institutes, pilgrimages, up to a religious schooling of children and young people, kindergartens etc. However, it would be wrong to regard "Milli Görüş" only as a charitable organization with Muslim character, as the public representation of the organization suggests ${ }^{10}$.

The most important political activities of "Milli Görüş" are mass gatherings ${ }^{11}$. The first annual meeting took place in Frankfurt in 1995. This series of events was continued in Antwerp (1996), Dortmund (1997) and Amsterdam (1998). The fifth and

8 Cf. www.igmg.de, Date: March 2007.

9 The "Milli" (e.g. "national") emphasises the genuine national orientation of the group. It is supposed to signal the disassociation from both communistic and too liberal trends.

10 Cf. www.igmg.de, Date: March 2007.

11 Cf. Interview with two representatives of Milli Görüş, Mr M.G. and Mr B.A., Date: 15.01.07. 
sixth annual meeting took place in Cologne in 1999 and 2000. In 2001 the annual meeting was cancelled by the organizers as a clear symbol of sympathy with victims of $11^{\text {th }}$ September. For the annual meeting 2002, the participants had to travel to Arnhem, a Dutch town close to the German border. It is worth mentioning that the annual meetings, usually taking place in football stadiums, were organized as both cultural festivals and annual meetings at the same time. If one considers the course of the events, the musical productions, the mood of the participants and the variety of activities, one can, without a doubt, confirm the festive character of the mass gatherings. Furthermore, the sub-groups, namely the women and youth's groups, celebrate their annual meetings as mass events. One should not forget a variety of political demonstrations to mark current occasions, such as the closure of the preacher schools in Turkey (1997).

The change within the activities of "Milli Görüş" was initiated by $11^{\text {th }}$ September 2001. As mentioned above, after that date all activities in connection to Islam were strongly linked, in the public and political discourse, to questions of risk. While "Milli Görüş̧" showed their "religious-revolutionary" character before more or less openly at mass demonstrations, after 9/11 they had to signal a stronger distancing from bonds to the country of origin. The transnational activities, which IGMG before conducted in two languages with totally different main emphases in a German and Turkish national context, could not be maintained because of the increased attention of surveillance organs to the revolutionary Islam ${ }^{12}$. The careful self-representation as a religious community is a way out of this situation. The public pressure, which "Milli Görüş" experiences because of its connection to Turkish Islamism, leads to a public representation of its transnational references in terms of the globally operating Umma ideology (Schiffauer, 2004). These changes in orientations of "Milli Görüşs" can be also understood with reference to the thesis of the deculturation of Islam (Roy, 2006). It implies that the initially ethnic bound Islam detaches itself from its cultural roots and strongly develops itself to a universal belief.

To sum up, "Milli Görüş" particularly emphasises its orientation towards the immigration society. Neither the history of the group, which was born of Islamist movements in Turkey, nor its Islamist symbols and goals, which are an obvious contradiction to public integration requests, are discussed today. Similar to DITIB, "Milli Görüş" is forced to publicly distance itself from acts of violence which are committed in the name of Islam. Thus, nowadays "Milli Görüsş" focuses on activities which are connected to the integration question. On the one hand, the association strives for a legal recognition as a religious community and, on the other hand, it fights for the recognition of Islamic religious education as a school subject. The organization cooperates with other Islamic organizations in Germany, such as DITIB, considering these questions. This cooperation mainly takes place within the scope of the Islamic conference (2006, 2007), organized by the federal Home Office. It needs to be mentioned that IGMG is the part of the association "Islamic Council", which

12 Today one can observe on "Milli Görüş" webpage that the Turkish and German version is identical, which was not the case before $9 / 11$. 
participates actively in the Islamic Conference. Thus, one can undoubtedly describe the politics of Milli Görüş in Germany as a "struggle for recognition"13 (Taylor, 1992; Schiffauer, 2004), which implies a far-reaching transformation of the political representation strategies of migrant's religious organizations.

\section{Alevitic Community Germany (Almanya Alevi Birlikleri Federasyonu/ AABF)}

The association $\mathrm{AABF}$ with its headquarter in Cologne was founded by seven Alevitic associations in 1991 and it is the central community of the "Federation of Alevitic Communities of Europe" (Avrupa Alevi Birlikleri Konfederasyonu/AABK). The fact that 'Muslim' migrants of Sunnite background are mainly the focus of the medial discourse makes it more important to pay attention to an Alevitic organization in which not only Turkish but also Kurdish migrants are organized.

Alevism refers to, from a Sunni perspective, a heterodox religious persuasion within Islam, which is mainly spread among Anatolian Turks. Even though Alevism was created as a kind of Shia, it maintained the pre-Islamic cultural elements and newly articulated them in an Islamic form. Without going into detail of the history of Alevism, it has to be mentioned that the institutionalisation of Alevitic organizations in Turkey has only been possible since the mid-1980s. The first public appearance of Alevitic intellectuals in Turkey took place in 1990, when a group of Alevitic intellectuals published an "Alevitic Declaration" (Öz, 1996).

The first "Federation of Alevitic Communities in Germany" (“Almanya Alevi Cemaatlari Federasyonu“) was already founded in Germany in January 1991. It was renamed "Alevitic Community of Germany" in 1992. It is worth mentioning that the Alevitic movement could count on the support of the European public because of its lasting disadvantages in Turkey. At the same time, the specific type of believe can explain the missing mistrust of Alevites in Europe: The Alevitic religiousness distances itself from some of the basic elements of majority Sunni Islam, such as the division of gender, veiling, five-times prayer in the mosque or the prohibition of alcohol, etc. Therefore, the Alevitic way of living does not give grounds for everyday life relevant, symbolically charged conflicts. The political preferences of Alevites, though, can be located in the left or rather social-democratic, laical camp.

The Alevitic Community of Germany, whose main goal is the "protection and development of cultural independence, religious and philosophical values of Alevites living in Europe", actively operated religiously and politically in a German as well as a

13 Both terms 'struggle for recognition' and 'identity politics' go back to the political philosophy of Charles Taylor (1992). They refer to the political engagement of minorities within the nation states, which, on the one hand, try to obtain the same political and legal equality as the majority of the population and, on the other hand, strive for the preservation of their own specific cultural identity. 
Turkish national context ${ }^{14}$. The transnational orientation of the community can be seen in the constitution of the association: The catalogue of demands of the Alevitic Community of Germany to the Turkish government comprises: 1) "constitutional recognition of Alevism", 2) "abolition of the Department of Religious Interests Diyanet in Turkey, this is the only possible way to realize the laical form of government", 3 ) "claims against the state to enable a free formation of religious institutes", 4) "request of a legal regulation of journalistic reporting on Alevism"15.

The expectations to the national authorities of Germany as well as other European countries include a catalogue of demands, which can be grasped with the famous term "identity politics". To this belong demands 1) for legal recognition of Alevitic organizations as a denomination, 2) for a consideration of Alevism in the school subject "religion and ethics": Alevism should not only be taught to migrant children but to all of them, 3) for an integration of scientific research on Alevism at German (and European) universities in disciplines, such as Turkish studies, Islam and the history of the Middle East, 4) support for practices of religious duties by local authorities - for example, by the establishment of praying houses (so-called CemHouses) in boroughs, and finally, 5) institutionalization of the migrant children's rights to learn their mother tongue ${ }^{16}$.

The specific activities of AABF unfold within the bounds of demands. The content analysis of the topics of the association's magazine "Alevilerin Sesi" suggests that the majority of the topics refer to Turkey. The association cooperates with other Alevitic organizations in Turkey, especially concerning the central question of an institutionalisation of the Alevitic belief in Turkey. At the moment AABF is intensively involved in the debate on Diyanet's existence in Turkey because, despite of neutral legal regulation, this influential religion department prefers Sunni Islam (Tezcan, 2003). Thus, AABF protested against the plans of the Turkish government to send Alevitic clergymen (Dedes) to Europe with the help of Diyanet ${ }^{17}$.

The AABF activities referring to Germany concentrate on the debates about obligatory religious education at state-owned schools. Even though Alevites in Turkey and Europe work closely together, there are some disagreements in problem depictions. While Alevites in Turkey want a general abolition of religious education, AABF rather prefers the German model of religious freedom: religious communities determine the content of religious education themselves ${ }^{18}$.

Partly, the German authorities benevolently correspond to the demand of the association. The Alevitic religious education was accepted in Berlin for the first time in 2002. Furthermore, there are plans for an Alevitic religious education in at least three

14 Cf. the program of the AABF, www.alevi.com, Date: January 2007.

15 Cf. ibid.

16 Cf. ibid.

17 Cf. “Almanya'ya Dede Yollayan Diyanet", Radikal, Date: 05.02.2007.

18 Cf. Interview with a representative of AABF, Mr I.K., Date: 04.12.2006. 
towns in Baden-Wurttemberg in 2006/07. In North Rhine-Westphalia, Bavaria and Hesse Alevitic education can be offered at a minimum of 12 participants ${ }^{19}$. Thus, the recognition of $\mathrm{AABF}$ as a religious community as well as its acceptance as a public cooperation is the centre of attention for the association's work. Especially the religious education plays an important role because in Germany, in contrast to Turkey, it can be planned by religious communities themselves. This fact gives additional expression to the institutional legitimacy of the religious community in question. This goal - the recognition of the Alevitic Community of Germany as a public cooperation was explicitly added to the constitution of the AABF.

To sum up, the political strategies of AABF - in Germany as well as Turkey can be described as public discussion performances: Apart from the publication of press statements and occasional organization of political demonstrations (e.g. coorganization of the protest activities against the presidential candidature of Tayyip Erdoğan in Ankara in April 2007), the AABF took part in the German Islamic Conference 2006 and 2007. The targets of political activities on the Turkish part are, on the one hand, the Turkish government authorities and, on the other hand, the left-wing democratic opposition in which the Alevites play an important role. The situation in Germany is different. The ABBF communicated with both, Churches and authorities. In the whole, the Alevitic Community in Germany operates openly in transnational spaces: because of the discriminated position of the Alevitic movement in Turkey, the usual integration requests of German politicians, directed to the Sunni associations, do not arise.

\section{POLITICAL TOPICS, STRATEGIES AND ADDRESSEES OF TURKISH POLITICAL ASSOCIATIONS}

\section{Federation of Democratic Workers' Associations (Demokratik İşçi Dernekleri Federasyonu / DIDF)}

The "Federation of Democratic Workers' Associations" leans to the formerly dominant political paradigm of class conflict. This association, dating back to the Maoist movement in Turkey, remains loyal to the idea of "international solidarity of the working population in the anti-imperialistic battle against international assets" 20 . The association was founded by the union of several Turkish origin workers' associations, in Bielefeld in 1980. At the moment there are 33 local member associations with 2,000 members throughout Germany. The association publishes a German magazine called "Young voice" and supports the Turkish magazine "Evrensel" (i.e. "The Universalist").

DIDF's activities are partly directed towards Turkey. Thus, the association maintains cooperation with human rights organizations and trade unions in Turkey. It supports the battle against torture and the death penalty. These activities are expressed

19 Cf. www.alevi.com/aabf, Date: January 2007.

20 Cf. www.didf.de, Date: March 2007. 
in different ways: On the one hand, the association published statements; on the other, the association invites Turkish guests to its celebrations ${ }^{21}$. However, DIDF concentrates a majority of its activities on Germany. In the centre of attention are those activities which are connected to the integration debate. Although DIDF was not invited to take part in the Integration Summit (2006, 2007), the association publicly voiced and addressed its statements to the participants of the Summit. The proposals in connection to the integration question are mainly directed towards state authorities. They include 1) the proposal of support of language courses for immigrants, 2) criticism of the public stigmatisation of migrants by constantly taking up topics such as "forced marriage" and "honour killings", 3) request of the introduction of the Turkish mother tongue at schools, e.g. in form of a foreign language subject, 4) finally, the request to replace religious education lesson with "history of religions lessons" 22 . The increasing public debate about religious questions in connection to integration problems, which started approximately 2001, is also observed by DIDF. However, it is interpreted, in a Marxist sense, as a diversion from the real problem of people ${ }^{23}$.

The less DIDF takes part in religion-political debates, the more it concentrates on the political discussion of political questions, such as unemployment, a low level of education of immigrants, health questions and questions of social protection. Therefore, it is not surprising that the association cooperates with the left-wing parties in Germany concerning these topics. Thus, DIDF directly cooperates with WASG ("Election Alternative") and with "Die Linke/PDS" as well as labour unions. The association publicly supported the left-wing party "Die Linke/PDS" at the last elections of parliament in September 2006. In addition it regularly joins the demonstrations of the German Association of Unions. Apart from these demonstrations and traditional Mai-rallies, the DIDF also organizes protest events: for example the signature collection "Say 'no' to loyalty testing! Say 'yes' to naturalization" (2006), was joined by famous politicians such as Oskar Lafontaine and Lothar Bisky.

To sum up, the internationalist orientation of DIFD does not lead to tensions between the transnational bonds of the association and public integration requests. The articulation of national and cultural interests is not important for DIDF because the integration-relevant questions are regarded through the prism of universal class identity. For this reason, the public debate is not denounced as an integration hindrance.

\section{Turkish Community in Germany (Almanya Türk Toplumu / TGD)}

The "Turkish Community in Germany" was founded by the union of different umbrella organizations in Hamburg in 1995. The main emphasis of the association is to represent the interests, requests and demands of Turkish-origin migrants to German national institutions and in public.

21 Cf. interview with Mr B. P., a representative of DIDF, Date: 29.11.2006.

22 Cf. DIDF's position paper, in: www.didf.de, Date: March 2007.

23 Cf. interview with the DIDF representative Mr B. P., Date: 29.11.2006. 
TGD explicitly stresses its reference to Turkey in its self-description. Thus, the first sentence of the association's constitution starts with the following words: "We, citizens of a Turkish origin, have permanently settles in the Federal Republic of Germany" 24 . In doing so they underline that they strive for more protection and support by the state "as a cultural minority". TGD declares its goal a "better communication between the German and Turkish nation by supporting a cultural exchange, youth welfare as well as education and occupational training" ${ }^{25}$. At the same time, they underline the consideration of Turkish political questions as an important task of the association. Furthermore, the TGB claims to be "independent of political and religious ideologies and autonomous from associations with conservative, liberal, socialdemocratic or religious orientations" $" 26$.

GD's political activities are diverse. The association issues publicly effective statements, press releases and PR campaigns, and organizes public conferences and events. One of the current tasks addressed by TGD is the replacement of the current German "policy on foreigners" with a "policy of equality". This aim is presented in a policy paper for Integration Summit in $2006^{27}$ :

"Law equality, the same possibilities of taking part in political and social decision processes, as well as in the education system and world of work [should] be called basic preconditions... [for] integration" 28 .

These requests for recognition, which are addressed to both the German government authorities and the public, are accompanied by demands for dual citizenship of migrants ${ }^{29}$. Another important role is also assigned to the local right to vote. At the same time an intercultural reorganization of the civil service, the introduction of a quota (approx. 10\% of all employment) according to the new multiculturalism debate are demanded. Finally, the achievement of the so-called intercultural opening of the education system: "this means to revise the framework plan - this has to be applied to all subjects - in such a way that the prevailing culture of origin, language and religion can find some room in it". Thus, according to the new support of bilingual education, German-Turkish Europe-Schools, similar to the ones already existing in Berlin, should be established in other federal states. The range of demands goes as far as naming streets after celebrities from the migration country and the establishment of programs in the Turkish language ${ }^{30}$.

24 Cf. Constitution, in: www.tgd.de, Date: March 2006.

25 Cf. ibid.

26 Cf. ibid.

27 The Integration Summit was organized by the Federal Home Office 2006 and 2007. But TGD only participated in the first meeting 2006. After changes in the Foreigners Law 2007 TDU avoided the Summit and thus protested against it.

28 Cf. Position paper of TGD "Equality and participation politics instead of a policy on foreigners" 2006, p. 3.

29 Despite of few exceptions German law aims to avoid dual citizenship. After the law reform in 2000 the migrants` children can keep the dual citizenship until the age of 18 , then they have to decide between the German and the foreign citizenship.

30 Cf. Position paper of TGD "Equality and participation politics instead of a policy on foreigners" 2006: 9-28. 
Apart from these requests, TGD formulated a demands referring to religious questions which were presented at the Islamic Conference (2006). The association emphasised its laical? orientation and correspondingly demanded a school subject with the title "Islamic studies and ethics" 31 . These demands are pursued in cooperation with other Turkish origin associations such as DITIB and are directed towards German government authorities, the German public and, at the same time (especially concerning Turkey's EU accession) towards the Turkish public ${ }^{32}$.

To sum up, the political recognition of Turkish identity aimed at by TGD does not lead to political tension between transnational bonds and integration requests coming from TGD's environment. This perception cannot only be found within the organization but also within the federal German integration debate. On the one hand, this unproblematic compatibility of transnational references and integration political requests has to do with the fact that representatives of TGD are members of federal German parties (such as the SPD MPs Vural Öğer and Hakkı Keskin). On the other hand, it is connected to the association's impeccable laicist orientation and the resulting positive connotation of its integration politics. Finally, the Kemalistic character of the TGD saves the association from a negative positioning within the integration debate. The association avoids the discussion of life-practical cultural obstacles of everyday life, such as the question of headscarves or the participation of migrant children in swimming lessons, and relinquishes the Turkish-nationalistic attitude which propagates an insuperable distance between a western and non-western cultural environment.

\section{POLITICAL TOPICS, STRATEGIES AND ADDRESSEES OF TURKISH BUSINESS ASSOCIATIONS}

\section{Association of Turkish Entrepreneurs and Industrialists in Europe e.V. (Avrupa Türk Işadamlari ve Sanayicileri Derneği / ATIAD)}

The organization goals of ATIAD ${ }^{33}$ show transnational references: first of all, the association is supposed to function as a "bridge" or rather a "link" between Germany, the European Union and Turkey. This "bridging function" should particularly be expressed in economical dimensions by "reinforcing the economic relations (trade relations) between Turkey and Germany, as well as Turkey and other EU- and EFTAcountries" 34 . The second objective of the association is the Turkey's involvement in national markets and in the global economy. The aim is to inform members about

31 Cf. ibid.: p. 16.

32 Cf. interview with a TGD representative Ms S.S., Date: 15.01.2007.

33 The association (founded in 1992) represents medium-sized and large Turkish-origin enterprises and characterises itself as a "pioneer and advocate of Turkish entrepreneurship in Europe". The headquarter of the association, which consists 40 members, is in Düsseldorf, however the main work takes place in Ankara, Istanbul, Brussels, Luxembourg and Berlin.

34 Cf. constitution of ATIAD e.V., in: www.atiad.org, Date: November 2005. 
economic profit opportunities as well as legal prevailing conditions of potential markets. The third objective of ATIAD is the articulation of "line of business specific questions" to governments in Turkey, Germany and other European countries as well as the European Union. Furthermore, the interests of Turkish and Turkish origin entrepreneurs should be represented to the line of business and profession associations. Finally Turkey's full membership in the European Union should be achieved.

It is also possible to divide ATIAD's activities into economical and political types $^{35}$. ATIAD's political practices refer to both the discussion of relevant political questions and the development of strategies for solving them. These questions can be divided according to their content: 1) support of training/apprenticeship and 2) Turkey's accession o the EU.

(Ad 1) ATIAD developed three solutions for the "deficits" which exist in the field of apprenticeship of young people of Turkish origin. According to its own data, the members of the association provide a large amount of apprenticeship places for Turkish-origin or foreign young people. Furthermore, additional projects are initiated which support the creation of apprenticeship places for young people of Turkish origin. Thus, in 2003 an evaluation project in cooperation with the IHK and the job centre was conducted in Düsseldorf, in which potential non-German apprenticeship companies were determined. In addition, ATIAD regularly offers an apprenticeship price which is awarded to excellent young professionals of Turkish origin. Every two years prices are awarded in such areas as "craftman's certificate, apprenticeship, abitur ${ }^{36}$, degree and $\mathrm{PhD}(\ldots)$ to make the wide public aware of the brisance of the topic" 37 . The topic of apprenticeship was also intensively discussed with important German politicians (such as the then Chancellor Gerhard Schröder or the then North Rhine-Westphalian Minister-President Wolfgang Clement). Several times over the past years, the chairperson of ATIAD presented the situation of Turkish-origin enterprises as well as the apprenticeship problems of young people of Turkish origin at the national press conference Berlin.

(Ad 2) The question of an "accession of Turkey to the EU" is addressed to the state authorities in different forms: by establishing contacts with German, Turkish and EU politicians, by formulating "position papers" in which the attitude of ATIAD are formulated, and by written contacts with Turkish, German and European politicians. Hence, ATIAD's representatives personally visited both the German Chancellor (August 2005, November 2003) and the Bavarian Home Secretary Günter Beckstein (June 2004). Furthermore, an ATIAD delegation met the President of the European Parliament, Pat Cox (December 2003), in Brussels. In November 2003 the Turkish Prime Minister Tayyip Erdoğan welcomed ATIAD representatives. At these personal

35 Small or medium-sized Turkish enterprises which want to operate in the European market are supplied with information on the specifications of these markets.

36 "Abitur" is a school examination usually taken at the end of the $13^{\text {th }}$ year and approximately equivalent to the British A level.

37 Cf. ATIAD e.V. brochure 2005. 
meetings with representatives of German, Turkish and European politics, which have been extensively built up since 2000, ATIAD's recommendations (in form of position papers) have been passed on in an oral or written form ${ }^{38}$.

For instance, the ATIAD directed its written question to German politicians, such as Edmund Stoiber (2003) and Chancellor Gerhard Schröder, as well as the Turkish the Foreign Minister İsmail Cem (2001). Moreover, ATIAD sent its recommendations to England's Prime Minister Tony Blair (2002) and to the President of the European Parliament Pat Cox $(2002)^{39}$.

To sum up, the term "integration" is used by ATIAD with dual connotation. On the one hand, integration is linked to the individual levels of the individual migrants. Thus, ATIAD understands itself as a supporter of integration processes. The second meaning hints directly at the Turkey's political integration process in the EU. In this context the transnational orientations of the association function as an important resource for political negotiations.

\section{Müsiad Berlin e.V (Müstakil Sanayici ve İşadamları Derneği)}

Which political strategies does Müsiad Berlin ${ }^{40}$ develop in view of the integration demands from the outside? First of all, it is important to note that the association cultivates explicit transnational references. The name of the organization, as well as its constitution, hints at the symbolic connection between Müsiad Berlin e.V. and MÜSİAD Turkey. An example for this is the mentioning of the most important principle of Muslim entrepreneurship in the representation of organizational goals:

1. "We believe that the interest system cannot be a long-term working-method of economy".

2. "Enterprises, which can be accessed by the nation, whose capital is distributed and free of speculative influence, make the healthiest development of the country and of the national economy possible." 41

These moral concepts are important as a regulative for the entrepreneurial practice of the members of the associations. The essential organizational goals for Müsiad Berlin are, firstly, a promotion of "entrepreneurial activities of the members" and, secondly, negotiation activities between (smaller) Turkish businesses and German economic and political institutions ${ }^{42}$.

38 Cf. "Position paper" by ATIAD addressed to German Chancellor Gerhard Schröder, Date: August 2005.

39 Cf. Interview with the representative of ATIAD, Mr Esref Ünsal, Date: 2.11.2005.

40 This association of enterprises, which mainly represents business of small or medium size, was founded by companies of Turkish origin in Berlin in 1994. In 1996 the Müsiad associations came down to a total of more than 700 members in Germany.

41 Cf. www.muesiad-berlin.de, Date: 23.09.2005, cf. Visions and Goals.

42 Cf. constitution of Müsiad Berlin e.V., see also an interview with Mr Sevki Karasu, Date: 26.09.2005. 
The main part of the activities of the association can be described as economic socialisation performances ${ }^{43}$. A rather small part of the association's work is influenced by politically relevant aspects mainly concerning topics such as the "integration of minorities of Turkish origin in Germany" and political "integration of Turkey in the EU". First of all, the association offers its members a discussion forum for these topics, by offering workshops and seminars which favour a political formation of opinion, for example "Conference: EU and Turkey" (2003), seminar "Enlargement of EU to the East" (2004), seminar "Turks and Islam" (2005), seminar "Relationship EU - Turkey" (2005). Secondly, the association addresses its ideas, expectations and interests to German politicians as well as Turkish. Therefore, between 2003 and 2005 the association welcomed Turkish representatives of politics, such as the Tourism Minister Güldal Akşit (2003), the Turkish Prime Minister Tayyip Erdoğan (2005), Turkish Members of Parliament and the vice chairpersons of the Turkish governing party AKP, Şaban Dişli und Reha Denemeç (2003), the Turkish Ambassador Ali Irtemcelik (2004) and the Turkish President of Parliament Bülent Arınç (2004). The main thematic emphasis of these meetings refers to the relationship between Turkey and Germany but also to the relationship between Turkey and EU: For example, Prime Minister Erdoğan, who was the guest of honour at the 10-years celebration of Müsiad Berlin, emphasised that the "integration of Turkish-origin enterprises in Germany" can be seen as an "important contribution to the efforts for Turkey's accession to the EU". Also the members of the AKP (Adalet ve Kalkınma Partisi) discussed relevant political questions such as the "accession of Turkey to the EU", "the Immigrants Act" and "the political development in Turkey". At the meeting with the Turkish Ambassador politically important topics such as the "situation of Turkish migrants" as well as the "current political developments in Germany" were discussed. Müsiad Berlin proposed to conduct regular discussions to the attaché for work, education and economy, in order to work out common strategies to solve the problems of the Turkish and Turkish-origin population in Germany."44

The representatives of the Müsiad associations in Germany, one of them Müsiad Berlin e.V., also cultivate contacts to Turkish politicians directly in Turkey. In March/April 2003, a meeting between German Müsiad representatives and Turkish politicians, such as the Prime Minister and the chairperson of the governing party AKP (Adalet ve Kalkınma Partisi), Tayyip Erdoğan, the chairperson of the opposition party CHP (Cumhuriyet Halk Partisi), Deniz Baykal, the Ministry of Industry and Economy, Ali Coşkun, as well as the vice chairman of the AKP, Eyüp Fatsa, took place. In the meetings they discussed "the situation of Turks living in Europe". It is interesting to note that afterwards a new committee of the Turkish parliament was founded in order to deal with this question ${ }^{45}$. Furthermore, Müsiad Berlin e.V. addressed political expectations to German politicians. The association cultivates contacts to representa-

43 The business seminars, which are conducted two to three times a month, not only pass on economical information ("assessment of finances", "industrial law", "setting up business") to the members but political topics are also discussed.

44 Cf. www.muesiad-berlin.de, Date: 03.01.2006.

45 Cf. ibid. 
tives of the federal German parties. In January 2003, a delegation of the association visited the Berlin parliament, after receiving an invitation from the Turkish origin Member of Parliament Özcan Mutlu (Bündnis 90/Die Grünen). At this meeting "problems of the Turkish entrepreneurs in Berlin and Germany" were discussed, too ${ }^{46}$. Furthermore, the association is in contact with politicians of the CDU/CSU. In April 2004 it participated in a CDU forum on the "EU-membership of Turkey". In March 2005 Müsiad Berlin e.V. invited the CDU chairperson at the Berlin parliament to a "political breakfast". At the latter they not only addressed the "situation of Turkish entrepreneurs in Germany" but also such topics as "the Immigrant Act in Germany".

To sum up, when meeting with political decision makers, Müsiad Berlin e.V. discusses mainly political (and not economical) questions. In the introspective of the organizations the transnational reference is not perceived as an integration hindrance. At the same time the term "integration" has a dual meaning for the association: On the one hand, it is used in correspondence with the integration of immigrants of Turkish origin in Germany. According to the association, entrepreneurs of Turkish origin can directly support this. On the other hand, "integration" is regarded as the political integration of Turkey in the EU.

\section{German-Turkish Chamber of Industry and Commerce (Türk- Alman Ticaret ve Sanayi Odasi / TD-IHK)}

This organization, with its headquarters in Cologne, is a counterpart of the Turkey-based German-Turkish Chamber of Industry and Commerce, existing since 1994. While the latter represents the interest of German enterprises in Turkey, the TDIHK represents the interests of Turkish enterprises in Germany. At the same time the association regards itself as an "advocate for enterprises of Turkish origin in Germany". A positive image of the association was created by the honour memberships of the former German Chancellor Schröder and the Turkish Prime Minister Erdoğan.

The essential goals of the TD-IHK are: a) support of the economic relationship between Germany and Turkey; b) "contacts to the German and Turkish government, public corporations"; 3) accomplishment of activities which support Turkey's accession to the EU, as well as d) support of "training of bilingual qualified employees and executives" 47 . These issues structure the economic and political practices of the TD-IHK, which offers two to five events per month.

The public discussion of politically relevant questions as well as apprenticeship support of Turkish-origin young people can be regarded as the main political practices of the TD-IHK. Also the accession of Turkey to the EU is discussed from a political point of view at different events ${ }^{48}$.

46 Cf. ibid.

47 Cf. www.td-ihk.de, Date: January 2006.

48 Cf. association's brochure 2005. 
In the field of apprenticeship places the association tries to create additional apprenticeship places by giving advices to enterprises of Turkish origin based in Germany. According to the association the man-power of young people with an immigrant background should not be underestimated. Instead they should be given a chance to develop themselves into "qualified, bilingual and bicultural qualified workers and executives" 49 . The association, in connection with the Education Ministry, advises German, Turkish and Turkish origin enterprises in Germany on creating apprenticeship places. In addition the representatives of the TD-IHK also discussed further proposals related to this question of apprenticeship on the 2006/07 Integration Summit. It is noteworthy that, also in the case of TD-IHK, the transnational orientation of the chamber conditions the specific comprehension of the integration debate.

\section{Turkish-German business association Berlin-Brandenburg (Türk- Alman Berliği Bellin-Brandenburg / TDU)}

The political strategies of Müsiad Berlin mainly consist of the organization and institutionalization of the reliable circle of addressees of political partners. Comparable forms of communication can also be observed with the TDU ${ }^{50}$. This association can also be characterized through visible transnational references.

Apart from economical practices ${ }^{51}$, the association is dedicated to the discussion of political problems. These discussion processes can be divided according to their content into the following areas: 1) apprenticeship problems, 2) representation of entrepreneurship of Turkish origin towards political and economical institutions, 3 ) Turkey's accession to the EU and 4) request for an introduction of dual citizenship ${ }^{52}$.

(Ad 1) Apprenticeship procedures and chances of young people of Turkish origin are discussed; furthermore, solutions for these problems are worked out and presented. Thus, "problems at school, as well as on the job and apprenticeship market" are characterized as alarming. In connection with this, the TDU initiated "sensitization work" with state facilities. According to TDU proposals small businesses which create additional apprenticeships should be financially supported. In addition, there should also be apprenticeship places for young people with a migration background in statedowned organizations. The support of business start-up by "giving advice and providing uncomplicated small loans" would also help to improve the apprenticeship situation. It is characteristic for TDU to get in touch with influential institutions in Germany and Turkey to work on this problem. In June 2003, for example, the TDU, together with the

49 Cf. ibid.

50 In 2005 the association, which was founded in Berlin in 1996, consisted of 150 members. Similar to Müsiad Berlin e.V., the TDU represents small and medium-sized enterprises in Berlin and surroundings.

51 The business socialisation of enterprises with a migrational background is made possible in form of seminars, consultations and further education.

52 Cf. www.tdu-berlin.de, Date: January 2005. 
IHK (Chamber of Industry and Commerce), HWK (Chamber of Trade), Berlin Senate for Economy, as well as the consulate general of Turkey, took part in the job centre initiative "Turkish enterprises for more apprenticeship places"53.

(Ad 2) The TDU regards itself as the junction between economical and political institutions in Germany as well as migrants of Turkish origin in BerlinBrandenburg. It is obvious that the association is also regarded as such as junction by economical and political institutions in Germany. This can be detected, for example, in the fact that both politically and economically important people attended TDU's last general meeting in Mai 2005: Berlin's mayor, the Turkish consul general, the presidents of the IHK and HWK. The TDU is regarded as an expert organization for economy of Turkish origin and involved in decision making processes of state committees in Berlin ${ }^{54}$. Furthermore, today - in contrast to its start-up period - they successfully cooperate with chambers of trade (IHK and HWK). Additionally the TDU is in contact with other organizations which represent the interests of migrant with a Turkish origin. They especially cooperate with the Turkish German Community (TGD) in questions concerning the "social-political integration" of immigrants of Turkish origin. The TDU also represents Turkish-origin enterprises at numerous seminars and conferences ${ }^{55}$. Worth mentioning is that the TDU represents the interest of Berlin enterprises not only to the German authority but also to the authority of Turkish politics. Thus, they negotiated export/import questions with the Turkish Foreign Trade Ministry.

(Ad 3) However, the TDU does not only mentally support Turkey's accession to the EU: in June 2004 before the elections for the European Parliament, the association appealed to its members to vote only for parties that support Turkey's EUmembership. The question of Turkey's membership is discussed with both, Turkish politicians (e.g. during the visit of a Turkish AKP delegation in June 2004) and German politicians (representatives of FDP, SPD. CDU, die Grünen and Linke/PDS). Thus, they disapprove of the anti-Turkish politics of the CDU, such as the circular by Angela Merkel to the heads of government and commission members of the EU, in which she argued against Turkey's accession to the EU.

(Ad 4) Furthermore, the TDU wants to achieve a lifelong dual citizenship for migrants offspring. They hope to accelerate the political decision processes by publicly expounding the problems of citizenship regulations.

In sum, the association regards its transnational bonds as politically relevant but not necessarily helpful for integration in a classic sense. Although it argues that the chances for an apprenticeship for young people of Turkish origin in Germany should be

53 The TDU helps Turkish-origin enterprises which create new apprenticeship place with bureaucratic formalities (cf. management report TDU 07.06.2003-21.05.2005: 8 ff., 30ff.).

54 The TDU is a member of the controlling committee of the Alliance for Economy and Employment in the Friedrichshein/Kreuzberg district in Berlin (cf. management report TDU, time period: 07.06.2003-21.05.2005: 10)

55 Cf. ibid: $30 \mathrm{ff}$. 
improved, the association insists on changing the basic political conditions of Turkish origin minorities through mechanisms such as tolerance of dual citizenship. Consequently, from the perspective of the association, the integration of the Turkish-origin minority in Germany can only be accomplished by political recognition of its transnational linkages.

\section{CONCLUSION}

The shift of our empirical research to an organizational level of migrant activities points out the necessity to rethink the role of migrant associations in the receiving countries. In addition, we have to discuss tree points from transnational perspective: firstly, the sociological understanding of the term 'integration' and, secondly, the positioning of migrant organizations within the so-called integration processes.

At the beginning of this article 'integration' is defined as a two-way-process which, on the one hand, is expressed in the interaction between national authorities and individuals and, on the other, in the interaction between national authorities and migrant associations. The article refers to the latter and emphasizes that especially discussion performances of migrant associations can be regarded as central political activities in this connection. This result hints at the discursive dimension of interaction processes between the nation state and migrant associations. From this perspective 'integration' can be regarded as a public 'definition struggle' or as a public negotiation of cultural and identity boundary drawing processes.

This public negotiation of boundaries between majorities and minorities can be found in two forms, media discussions and symbolically charged political events - such as the Islamic Conference (2006, 2007) and the Integration Summit (2006, 2007 ) in which most of the associations took part in. As one can see, associations play a central role in the construction of the national integration discourse. At the same time their public reference to the topic 'integration' is a specific form of identity work, e.g. a specific form of self-description of associations (Rauer, 2008: 190). In this context, transnational linkages obtain a specific symbolic meaning within the integration discourse. The appearance of transnational references in the discursive field is also regulated by the distribution of spokesperson positions, the connections of utterances, as well as the reference to related or adjoined discourses.

As we have seen the spokesperson position of migrant associations is restricted by nation state authorities. It is visible especially in cases of the above mentioned conferences such as the Islamic conference and the Integration Summit which are organized by the Federal Home Office. Apart from this aspect, the public presentations of associations' transnational linkages are organized by the semantic scheme of 'support or non-support of integration'. This rule of statements production constructs a semantic boundary between 'Us' and 'Them'. But the term 'integration' refers to the process-related dimension of societal life, this is why the construction of boundaries in this case can be better grasped by the scheme of "Joining Us" or "Staying Other". Therefore, transnational linkages can always be mentioned whenever 
it is necessary to present them as resources for integration. In other words, transnational linkages are re-interpreted in the context of the integration debate. Additionally, we have pointed out that although all analyzed associations actively take part in the public integration discussions, their public strategies concerning transnationality differ significantly. The religious associations analyzed above try to present their transnational bonds as no hindrance for integration. Moreover, particularly such associations as DITIB and IGMG prefer to avoid the discussion of their transnational activities especially since 9/11. In opposition, the business and political associations discussed above stress their belonging to the plural national context. They regard their transnational bonds as knowledge competences which are useful and even necessary for bringing integration processes ahead. This difference of statement construction is caused by a partial link of transnational references and religious debates, in other words by inter-discursive connections.

Two points have to be distinguished in this case. Firstly, in the German context the public mistrust regarding religious organizations of migrants' refers to the suspiciousness of their view on the relationship between politics and religion. The dominant public assumption is that religious associations organize their political activities on the basis of religious principles. This suspicion is especially high in regard to the Sunni Muslim associations DITIB and IGMG, although one has to mention that the latter actually practices in such a way. However, the idea that boundary between politics and religion can vanish, puts the central premise of western nations states into question. Concomitantly, the reference to transnational linkages in the cases of DITIB and IGMG would increase such suspicions and cause their labelling as not willing to integrate. In the public debate they would be defined as 'Staying Them' and not as 'Joining Us'. Secondly, some current trends in the global societal frame condition the connection between transnationality, religious discourse and global risk perception. Especially after 9/11 the perspective of western states on religious matters has been transformed, whereas religious questions become the priority of the political agenda (Eisenstadt, 2007). This global trend constrains also the activities of Turkish religious associations in Germany.

In opposite to Sunni religious associations, political and business associations of migrants promote principles and statements which are highly accepted on the political agenda, because they are based on the re-formulated idea of equality. This idea expresses itself in the so-called 'identity politics', which aim, on the one hand, to achieve equal political rights and, on the other, to recognize the cultural difference of minorities (Taylor, 1992). The connection between 'identity politics' and transnational references is accepted in German public debates. Transnational linkages are re-defined by business and political associations as a cultural basis which enables the representation of migrants' cultural otherness. Because they aim at an acceptation of their cultural specificity, they remove transnational linkages from a private to a public sphere. From their point of view, only the recognition of their cultural otherness by state authorities and the German public allows a successful integration. In other words, they stress the possibility of simultaneous belonging to both positions: 'Staying Other' and 'Joining the Majority'. Their public self-description follows, therefore, the semantical rule of inclusion of different social items, the so-called 'both/and'-logic of transnationality. 
To sum up, the survey of political activities of Turkish migrant associations in Germany has shown that the associations have taken over a specific spokesperson position within the German integration discourse. Nevertheless, they can only partially influence the rules of discursive statement production due to a restricted access to societal definition processes. However, they are capable of shifting the semantic boundaries of 'Us' and 'Them' in the national integration discourse through communicative references to transnational linkages. From the transnational perspective, this accomplishment can be regarded as a contribution to the accommodation which is understood as a negotiation of mutual cooperation of majorities and minorities. 


\section{Appendix:Research Sources}

\begin{tabular}{|c|c|c|}
\hline Associations & Interview partner & Additional Sources \\
\hline $\begin{array}{l}\text { DITIB } \\
\text { Turkish-Islamic } \\
\text { Union of the } \\
\text { Presidency of } \\
\text { Religious Affairs, } \\
\text { founded in } 1984 \\
\text { (DITIB joins } \\
\text { religious commu- } \\
\text { nities, whose } \\
\text { members belong to } \\
\text { all social layers) }\end{array}$ & $\begin{array}{l}\text { Interview with the } \\
\text { representative of DITIB, } \\
\text { Mr B. A., Date: } \\
\text { 24. 11.2006. }\end{array}$ & $\begin{array}{l}\text { 1) Interview with chairman of DITIB Mehmet Yıldırım, in: } \\
\text { Frankfurter Allgemeine Zeitung, Date: 9.2.2005. } \\
\text { 2) „Das Kopftuch ist uns nicht so wichtig“. Interview with the } \\
\text { chairman of DITIB Ridvan Cakir. In: „Die Zeit“, Date: } 03.06 .2004 \text {, } \\
\text { No. } 24 \text {. } \\
\text { 3) www.diyanet.org/de/startseite/archive.php?start=10\&first=1 } \\
\text { Date: March 2007. } \\
\text { 4) www.bmi.bund.de, Date: } 01.12 .2006 \text {. } \\
\text { 5) Press releases of “Coordination Committee of Muslims”, } \\
\text { www.islam.de, Date } 01.12 .2007 \text {. } \\
\text { 6) Cf. www.bundesregierung.de/Content/DE/Artikel/2006/07/2006-07- } \\
\text { 14-pressekonferenz-integrationsgipfel.html, Date: November 2006. }\end{array}$ \\
\hline $\begin{array}{l}\text { IGMG } \\
\text { Islamic Community } \\
\text { Milli Görüs, } \\
\text { founded in } 1985 \\
\text { (IGMG joins } \\
\text { religious communi- } \\
\text { ties, whose members } \\
\text { belong to middle } \\
\text { and lower layers) }\end{array}$ & $\begin{array}{l}\text { Interview with the } \\
\text { representative of } \\
\text { Milli Göruş, Mr M.G., } \\
\text { Date: } 15.01 .07 . \\
\text { Interview with the } \\
\text { representative of } \\
\text { Milli Göruş, Mr B.A., } \\
\text { Date: } 15.01 .07 .\end{array}$ & 1) www.igmg.de, Date: March 2007, April 2007. \\
\hline $\begin{array}{l}\text { AABF } \\
\text { Alevitic } \\
\text { Community } \\
\text { Germany, founded } \\
\text { in } 1991 \\
\text { (AABF joins } \\
\text { religious communi- } \\
\text { ties, whose members } \\
\text { belong to all social } \\
\text { layers) }\end{array}$ & $\begin{array}{l}\text { Interview with the } \\
\text { representative of AABF, } \\
\text { Mr I. K. (AABF), } \\
\text { Date: } 04.12 .2006 .\end{array}$ & $\begin{array}{l}\text { 1) www.alevi.com, Date: January } 2007 . \\
\text { 2) Article "Almanya'ya Dede Yollayan Diyanet", Radikal, Date: } \\
05.02 .2007 \text {. }\end{array}$ \\
\hline $\begin{array}{l}\text { DIDF } \\
\text { Federation of } \\
\text { Democratic } \\
\text { Workers' } \\
\text { Associations, } \\
\text { founded in } 1980 \\
\text { (DIDF joins sub- } \\
\text { organizations, } \\
\text { whose members } \\
\text { belong to middle } \\
\text { and lower social } \\
\text { layers) }\end{array}$ & $\begin{array}{l}\text { Interview with the } \\
\text { representative of DIDF, } \\
\text { Mr B. P., } \\
\text { Date: } 29.11 .2006 .\end{array}$ & $\begin{array}{l}\text { 1) Article “Almanya'ya Dede Yollayan Diyanet”, Radikal, Date: } \\
\text { 05.02.2007. } \\
\text { 2) www.didf.de, Date: March } 2007 .\end{array}$ \\
\hline
\end{tabular}




\begin{tabular}{|c|c|c|}
\hline Associations & Interview partner & Additional Sources \\
\hline $\begin{array}{l}\text { TGD } \\
\text { Turkish Community } \\
\text { in Germany, } \\
\text { founded in } 1995 \\
\text { (TGD joins sub- } \\
\text { organizations, whose } \\
\text { members belong to } \\
\text { middle and lower } \\
\text { social layers) }\end{array}$ & $\begin{array}{l}\text { Interview with the } \\
\text { representative of TGD, } \\
\text { Ms S.S., Date: 15.01.07. }\end{array}$ & $\begin{array}{l}\text { 1) Position paper of TGD “'Equality and participation politics' } \\
\text { instead of a 'policy on foreigners"”, } 2006 . \\
\text { 2) www.tgd.de, Date: October 2006, March 2006, March } 2007 .\end{array}$ \\
\hline $\begin{array}{l}\text { ATİAD } \\
\text { Association of Turkish } \\
\text { Entrepreneurs and } \\
\text { Industrialists in } \\
\text { Europe, founded in } \\
1992 \\
\text { (ATIAD joins sub- } \\
\text { organizations, whose } \\
\text { members belong to } \\
\text { upper and middle } \\
\text { social layers) }\end{array}$ & $\begin{array}{l}\text { Interview with the } \\
\text { representative off ATİAD } \\
\text { e.V., Mr Esref Ünsal, } \\
\text { Date: } 2.11 .2005 .\end{array}$ & $\begin{array}{l}\text { 1) ATIAD brochure (2005). Düsseldorf. } \\
\text { 2) ATIAD-Position Paper for the Meeting of a delegation of } \\
\text { Turkish entrepreneurs with Chancellor Gerhard of the Federal } \\
\text { Republic of Germany, Berlin, Date: } 26 \text { August } 2005 \text {. } \\
\text { 3) www.atiad.org, Date: November: } 2005 \text {. } \\
\text { 4) Association's Magazin "Ekonomi Dergisi" (Since } 2002 \text { the } \\
\text { bilingual magazine is published every other month and directed to } \\
\text { the needs of a German and Turkish economic public.) }\end{array}$ \\
\hline $\begin{array}{l}\text { Müsiad Berlin } \\
\text { Association of Turkish } \\
\text { Entrepreneurs in } \\
\text { Berlin, founded in } \\
1994 \\
\text { (Müsiad Berlin joins } \\
\text { enterprises, whose } \\
\text { members belong to } \\
\text { middle and lower } \\
\text { social layers) }\end{array}$ & $\begin{array}{l}\text { Interview with the } \\
\text { representative of Müsiad } \\
\text { Berlin e.V., Mr Sevkii } \\
\text { Karasu, Date: } \\
\text { 26.09.2005. }\end{array}$ & $\begin{array}{l}\text { 1) Müsiad Berlin e.V. broshure (2005). } \\
\text { 2) www.müsiad-berlin.de, Date: January } 2006 .\end{array}$ \\
\hline $\begin{array}{l}\text { TD-IHK } \\
\text { German-Turkish } \\
\text { Chamber of Industry } \\
\text { and Commerce, } \\
\text { founded in } 1994 \\
\text { (TD-IHK joins } \\
\text { enterprises, whose } \\
\text { members belong to } \\
\text { upper and middle } \\
\text { social layers) }\end{array}$ & $\begin{array}{l}\text { Interview with the } \\
\text { representative of TD- } \\
\text { IHK, Mr Kemal Sahin, } \\
\text { Date: } 9.11 .2005 .\end{array}$ & $\begin{array}{l}\text { 1) TD-IHK brochure (2005). Köln. } \\
\text { 2) www.td-ihk.de, Date: January } 2006 .\end{array}$ \\
\hline $\begin{array}{l}\text { TDU } \\
\text { (Turkish-German } \\
\text { business association, } \\
\text { founded in 1996) } \\
\text { (TDU joins } \\
\text { enterprises, whose } \\
\text { members belong to } \\
\text { middle and lower } \\
\text { social layers) }\end{array}$ & $\begin{array}{l}\text { Interview with the } \\
\text { representative of TDU } \\
\text { Berlin-Brandenburg e.V., } \\
\text { Mr Ahmet Ersöz, Date: } \\
\text { 13.11.2005. }\end{array}$ & $\begin{array}{l}\text { 1) www.tdu-berlin.de, Date: January } 2005 \text {. } \\
\text { 2) Management report of the TDU (timeperiode: } 07.06 .2003 \text { - } \\
\text { 21.05.2005). }\end{array}$ \\
\hline
\end{tabular}




\section{References}

BRETON Raymond (1964) Institutional Completeness of Ethnic Communities and the Personal Relations of Immigrants, in American Journal of Sociology, vol. 70, pp. 193-205.

EISENSTADT Shmuel (2007) The Reconstitution of Collective Identities and Inter-Civilizational Relations in the Age of Globalization, Wohlrab-Sahr Monika and Levent Tezcan eds., Konfliktfeld Islam in Europa, Soziale Welt, Special Issue 17, Nomos, Baden-Baden, pp. 2132.

ESSER Hartmut (2001) Integration und ethnische Schichtung, Working Paper Nr. 40, Mannheim, Mannheimer Zentrum für Europäische Sozialforschung.

FAIST Thomas (1995) A Preliminary Analysis of Political-Institutional Aspects of International Migration: Internationalization, Transnationalization, and Internal Globalization. Working Paper No.10/95, Bremen, Centre for Social Policy Research.

FAIST Thomas (2000) The Volume and Dynamics of International Migration and Transnational Social Spaces, Oxford, Oxford University Press.

GEIßLER Rainer and PÖTTKER Horst eds. (2006) Massenmedien und die Integration ethnischer Minderheiten in Deutschland. Bielefeld, Transcript.

HEITMEYER Wilhelm and MÜLLER Joachim and SCHRÖDER Helmut (1997) Verlockender Fundamentalismus. Türkische Jugendliche in Deutschland, Frankfurt/M., Suhrkamp.

JUNGK Sabine (2000) Selbstorganisation von Migrantinnen und Migranten - Instanzen gelingender politischer Partizipation, IZA - Zeitschrift für Migration und Soziale Arbeit, vol. $3 / 4$.

KELLER Reiner (2005) Wissenssoziologische Diskursanalyse - Grundlegung eines Forschungsprogramms. Wiesbaden, Verlag für Sozialwissenschaften.

KNEER Georg (1997) Nationalstaat, Migration und Minderheiten. Ein Beitrag zur Soziogenese von ethnischen Minderheiten, Nassehi Armin ed. Nation, Ethnie, Minderheit. Beiträge zur Aktualität ethnischer Konflikte. Köln/Weimar/Wien, Bühlau, pp. 85-102.

KOOPMANS Ruud and STATHAM Paul (2001) How National Citizenship Shapes Transnationalism. A Comparative Analysis of Claims-Making in Germany, Great Britain and the Netherlands, University of Oxford, Transnational Communities Programme, Working Paper Series, Oxford, WPTC-01-10.

ÖZ Baki (1996) Alevilik Nedir? İstanbul, DER Yayınları.

ØSTERGAARD-NIELSON Eva (2003) Transnational Politics. Turks and Kurds in Germany. Routledge, London and New York.

PRIES Ludger (2008) Transnationalisierung sozialer Welt. Sozialräume jenseits von Nationalgesellschaften.Frankfurt am Main, Surhkamp.

RAUER Valentin (2008) Die öffentliche Dimension der Integration. Migrationspolitische Diskurse türkischer Dachverbände in Deutschland. Transcript Verlag, Bielefeld.

RECKWITZ (2001) Multikulturalismustheorien und Kulturbegriff. Vom Homogenisierungsmodell zum Modell interkultureller Interferenzen. Berliner Journal für Soziologie, vol. 11/2, pp. 179-200.

ROY Oliver (2006) Der Islam in Europa - eine Ausnahme? Aus Politik und Zeitgeschichte, vol. 28/29, pp. 5-11.

RUHRMANN Georg, SOMMER Denise and UHLEMANN Heike (2006) TV-Nachrichtenberichterstattung über Migranten - von der Politik zum Terror, in: Geißler Rainer and Horst Pöttker eds. Massenmedien und die Integration ethnischer Minderheiten in Deutschland, Bielefeld, Transcript, pp. 149-187.

STRAUSS Arnselm (2007) Grundlagen qualitativer Sozialforschung. Datenanalyse und Theoriebildung in der empirischen und soziologischen Forschung, second edition, UTB, Stuttgart. 
TAMBIAH Stanlay (2000) Transnational Movements, Diaspora and Multiple Modernities, Deadalus, vol. 129, Nr. 1: pp. 163-194.

TAYLOR Charles (1992) Multiculturalism and "The politics of recognition": An Essay. Princeton, New York: Princeton University Press.

TEZCAN Levent (2003) Religiöse Strategien der „machbaren“ Gesellschaft. Verwaltete Religion und islamistische Utopie in der Türkei. Bielefeld, Transcript.

TECZAN Levent (2005) The Problems of Religious Modernity. The Asian Journal of Social Science (AJSS), vol. 33, pp. 506-528.

TEZCAN Levent (2007) Kultur, Gouvernementalität der Religion und der Integrationsdiskurs, in Wohlrab-Sahr Monika and Levent Tezcan eds., Konfliktfeld Islam in Europa, Soziale Welt, Special Issue 17, Nomos, Baden-Baden, pp. 89-110.

TRÄNHARDT Dieter and HUNGER Uwe eds. (2003) Migration im Spannungsfeld zwischen Nationalstaat und Globalisierung, Leviathan-Special Issue, vol. 22, Opladen, Westdeutscher Verlag.

ZENGINGÜL Tülay (2007) Der Dialogdiskurs, Der Bericht aus dem Projekt „Macht und kulturelle Behauptung in der interreligiösen Kommunikation “, Faculty of Sociology, University of Bielefeld, Unpublished paper. 


\title{
Les associations turques de migrants en Allemagne : entre pression à l'intégration et liens transnationaux
}

\author{
Anna AMELINA et Thomas FAIST
}

\begin{abstract}
Contrairement à l'affirmation selon laquelle les activités transnationales des organisations migrantes sont surtout déterminées par les cadres institutionnels, cet article part du principe que les pratiques des organisations transnationales des migrants sont aussi marquées par la façon dont ces organisations articulent leur orientation transnationale avec l'impératif de l'intégration. Par conséquent cet article poursuit la question de savoir comment des organisations migrantes orientées de façon transnationale gèrent la pression à l'intégration.

Cette problématique a été développée à partir des associations et organisations religieuses, politiques et économiques turques en Allemagne. L'hypothèse est que l'intégration est un champ discursif et complexe, dans lequel les associations migrantes représentent un porteparole spécifique. Malgré le fait que toutes les associations examinées ont participé aux débats sur l'intégration, il a été constaté qu'elles gèrent de manière très différente cette pression à l'intégration. Les associations religieuses, notamment sunnites, ont des difficultés avec la représentation publique de leur attachement transnational, en raison du terrorisme. Par contre, les associations politiques et économiques peuvent communiquer publiquement leur orientation transnationale et la mettre en avant. En même temps, ces associations relient leurs exigences d'égalité des droits des migrants à leurs liens transnationaux. Ainsi, bien que les associations migrantes turques aient un accès restreint aux processus de définitions sociales, les associations politiques et économiques en particulier, réussissent à interpréter l'impératif de l'intégration de façon nouvelle. Par conséquent elles se positionnent dans la discussion de l'intégration en tant qu'acteurs et elles occupent une double position sociale, en représentant dans la société d'immigration allemande l'" altérité » et en même temps les «non- étrangers ».
\end{abstract}

\section{Turkish Migrant Associations in Germany: Between Integration Pressure and Transnational Linkages}

\section{Anna AMELINA and Thomas FAIST}

In contrast to the thesis that transnational political activities of migrant communities and organizations are mainly influenced by the institutional pressure of nation states, the article argues that transnational politics of migrants are also determined by specific ways migrant associations connect their homeland orientation with public integration requests. Therefore, the paper focuses on the question how migrant associations, which cultivate transnational linkages, deal with state integration pressure. This conceptual statement was tested in the case study focused on political activities of selected religious, political and business associations of Turkish migrants settled in Germany. The presented research results are based on the relational perspective on integration processes and define integration as a discursive field in which migrant associations obtain a specific spokesperson position. One of the central research observations is that although all analyzed associations take part in integration debates, their ways of dealing with integration pressure differ decisively. The Sunni religious associations, for instance, cannot publicly present their transnational bonds because of the globally assumed danger of trans- 
national Islamic organizations. In contrast to them, political and business organizations can voice their transnational connections publicly and present them in a positive way, because the core activities of these associations are related to the identity politics. These aims are positively coloured by most political actors in Germany. They connect both, equalization requests and integration statements. To sum up, although the access of Turkish migrant associations to the public construction of definitions is limited, some of them, especially political and business associations, manage to redefine public integration requests and simultaneously to position themselves as both 'Non-foreign' and 'Other'.

\section{Las asociaciones de migrantes turcos en Alemania: entre la presión de la integración y las vinculaciones transnacionales}

\section{Anna AMELINA y Thomas FAIST}

En contraposición a la afirmación de que las actividades político-transnacionales de las organizaciones de migrantes dependen principalmente de las condiciones marco institucionales de los estados nacionales, el presente artículo parte del supuesto de que las prácticas transnacionales de las organizaciones de migrantes se ven también influenciadas por la manera en que ellas relacionan sus orientaciones transnacionales con las exhortaciones a integrarse.

Por consiguiente, el artículo atiende a la pregunta sobre de qué manera las organizaciones de migrantes transnacionalmente orientadas conviven con la presión a integrarse. Este problema ha sido examinado tomando como ejemplo a las organizaciones religiosas, políticas y económicas de las asociaciones turcas en Alemania. Los resultados de la investigación aquí presentados se basan en el supuesto de que integración es un complejo campo discursivo en el que las asociaciones de migrantes ocupan una posición específica de portavoz. Se constató que todas las asociaciones examinadas conllevan la presión a integrarse de manera claramente distinta, si bien es cierto que todas participan de los debates sobre integración. Las asociaciones religiosas de los sunitas por ejemplo, tienen dificultades con la representación pública de sus conexiones transnacionales, como consecuencia del discurso global sobre el terrorismo, mientras que asociaciones de migrantes políticas y económicas dan a conocer públicamente sus orientaciones transnacionales presentándolas bajo una luz positiva. Esto tiene que ver por otro lado, con el hecho de que sus actividades están dirigidas a lograr una así llamada política de identidad, cuyos principios elementales encuentran un gran reconocimiento en la agenda de los estados nacionales. Así mismo, estas asociaciones relacionan sus reivindicaciones de igualdad para los migrantes hacienda incapié de sus vínculos transnacionales. En resumen se puede decir que a pesar de que el acceso de asociaciones de migrantes turcas a los procesos de definiciones sociales es limitado, son principalmente las asociaciones políticas y económicas las que logran una nueva interpretación de las exhortaciones públicas a integrarse. Por lo tanto, ellas mismas se posicionan en el discurso de integración como los actores que al mismo tiempo ocupan dos posiciones sociales: Los "culturalmente distintos", como también los "no foráneos" en la sociedad alemana de inmigración. 